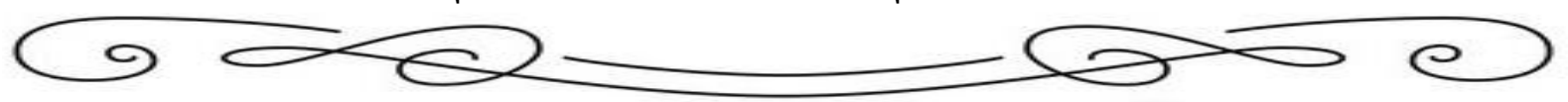

Удк 376-056.26:364.4-056.26

DOI: 10.31499/.3.2019.190396

\title{
ІНКЛЮЗИВНА ОСВІТА ДІТЕЙ 3 ФІЗИЧНИМИ ПОРУШЕННЯМИ ЯК ФАКТОР ЇХ СОЦІАЛЬНОЇ АДАПТАЦІЇ
}

Матрос Ольга, кандидат педагогічних наук, доцент кафедри соціальної педагогіки та соціальної роботи, Уманський державний педагогічний університет імені Павла Тичини.

ORCID: 0000-0001-6541-1941

E-mail: oljmatros@gmail.com

У статті висвітлено особливості нормативно-правової бази в Україні щодо забезпечення якісної та доступної інклюзивної освіти для дітей з інвалідністю та виокремлено ті статті законодавства, у яких прописуються психолого-педагогічні та корекційнорозвиткові послуги означеної проблеми. Описано принципи утворення інклюзивно-ресурсних центрів з метою забезпечення реалізації права на освіту та психолого-педагогічний супровід дітей з особливими освітніми потребами. Охарактеризовано етапи соціалізації у розвитку дитини з особливими освітніми потребами та їх адаптація.

Ключові слова: інклюзивна освіта, інклюзивно-ресурсні центри, діти з інвалідністю, соціальна адаптація, корекційно-розвиткові послуги, психолого-педагогічний супровід, адаптація, особливі освітні потреби.

\section{INCLUSIVE EDUCATION OF CHILDREN WITH PHYSICAL DISABILITIES AS A FACTOR OF THEIR SOCIAL ADAPTATION}

Matros Olha, PhD in Pedagogical Sciences, Associate Professor of the Department of Social Pedagogy and Social Work, Pavlo Tychyna Uman State Pedagogical University.

ORCID: 0000-0001-6541-1941

E-mail: oljmatros@gmail.com

The article highlights the peculiarities of establishing a legal framework in Ukraine for the provision of quality and accessible inclusive education for children with disabilities, who are provided with psycho-pedagogical, correctional and development services in the manner determined by the central executive authority in the field of education and science. The study describes the principles of creating inclusive resource centres to ensure the realization of the right to education, psychological and pedagogical support for children with special educational needs. The author characterizes stages of socialization in the development of a child with special educational needs and their adaptation.

It is emphasized that the study does not exhaust all aspects of the problem, and the further direction of the study may be the characterization of equipment, technologies and equipment for children with disabilities in inclusive education institutions. The acquisition itself and the opportunity to receive education in inclusive education institutions is a factor in the social adaptation of children with disabilities.

The integration of Ukraine into the European educational space compels our country to ratify international treaties every year and to provide open and accessible education for all children with disabilities at all its links. 


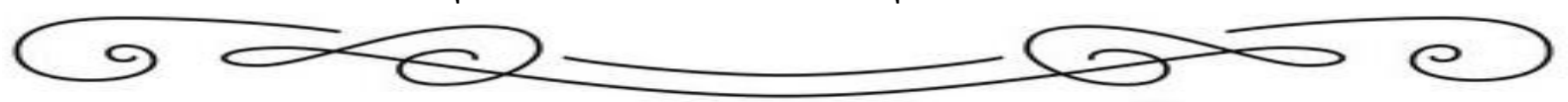

The social and economic conditions for successful socialization in society are: early identification of children with SEN; economic support for families raising a child with SEN; social and pedagogical work with disadvantaged families; social and pedagogical support of large and young families.

It is pointed out that the issue of introduction of innovations in education of persons with special educational needs is rather contradictory and at the same time, topical, which needs comprehensive study. Practitioners believe that inclusive education is an innovative, alternative model of education that is becoming urgent today.

Keywords: inclusive education, inclusive resource centres, children with disabilities, social adaptation, correctional and development services, psychological and pedagogical support, adaptation, special educational needs.

Актуальним питанням і досі в нашій державі залишається інклюзивна освіта. Адже, на думку дослідників С. Хамініч та О. Переверзевої «Інклюзивне навчання в загальноосвітніх закладах відображає одну з головних демократичних ідей - усі особи є цінними й активними членами суспільства. Інклюзія означає розкриття кожного особи за допомогою освітньої програми, яка $\epsilon$ достатньо складною, але відповідає його здібностям. Вона враховує потреби, а також спеціальні умови та підтримку, яка забезпечується медико-соціальним та психолого-педагогічним супроводом. Питання впровадження інновацій в освіту осіб $з$ особливими освітніми потребами досить суперечливе й водночас, актуальне, яке потребує всебічного вивчення. Практики - спеціалісти вважають, що інклюзивна освіта - це інноваційна, альтернативна модель освіти, що стає вимогою сьогодення. Мета нашої держави виплекати людину 3 освітніми потребами, яка необхідна Україні в третьому тисячолітті - професіонала та гідного громадянина України» [6]. Але, власне здобуття та можливість отримати освіту в закладах з інклюзивним навчанням - це $\epsilon$ фактором соціальної адаптації дітей з інвалідністю.

Питаннями інклюзивної освіти дітей з інвалідністю в Україні у закладах загальної середньої освіти та особливостями становлення й розвитку системи інклюзивної освіти займалися такі вчені, як М. Ажажа, Л. Будяк, Л. Левченко, I. Лікарчук, О. Переверзева, І. Сірополко, О. Федоренко, С. Хамініч та інші. Зокрема, А. Колупаєва та О. Таранченко здійснили періодизацію еволюції стосунків суспільства і держави до осіб з порушеннями в Україні. Дослідники, Н. Софій, М. Сварник, П. Троханіс приділяли увагу праву дітей 3 особливими освітніми потребами та рівний доступ до якісної освіти.

Мета статті - висвітлити, розкрити та дати оцінку особливостям інклюзивної освіти дітей з інвалідністю із фізичними порушеннями як фактор їх соціальної адаптації.

В Україні діє грунтовна нормативно-правова база щодо забезпечення якісної та доступної інклюзивної освіти для дітей з інвалідністю. Зокрема, стаття із Закону України «Про освіту» 2017 р. Право на освіту п. 2. В Україні створюються рівні умови доступу до освіти. Ніхто не може бути обмежений у праві на здобуття освіти. Право на освіту гарантується незалежно від віку, статі, раси, стану здоров'я, інвалідності, громадянства, національності, політичних, релігійних чи інших переконань, кольору шкіри, місця проживання, мови спілкування, походження, соціального і майнового стану, наявності судимості, а також інших 


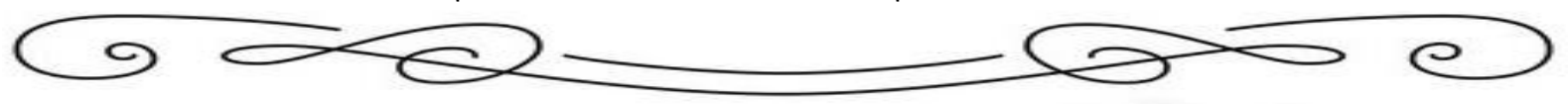

обставин та ознак.

А у п. 6 ст. 3 Закону України «Про освіту» зазначено, що: «Держава створює умови для здобуття освіти особами 3 особливими освітніми потребами 3 урахуванням індивідуальних потреб, можливостей, здібностей та інтересів, а також забезпечує виявлення та усунення факторів, що перешкоджають реалізації прав і задоволенню потреб таких осіб у сфері освіти».

Регламентація прав на інклюзивне навчання висвітлено у статті 19. Закону України «Про освіту» 2017 р.: «Освіта осіб з особливими освітніми потребами». У якій йде мова про те, що 1.Органи державної влади та органи місцевого самоврядування створюють умови для забезпечення прав і можливостей осіб з особливими освітніми потребами для здобуття ними освіти на всіх рівнях освіти 3 урахуванням їхніх індивідуальних потреб, можливостей, здібностей та інтересів.

2. Держава забезпечує підготовку фахівців для роботи 3 особами 3 особливими освітніми потребами на всіх рівнях освіти.

3. Особам з особливими освітніми потребами освіта надається нарівні 3 іншими особами, у тому числі шляхом створення належного фінансового, кадрового, матеріально-технічного забезпечення та забезпечення розумного пристосування, що враховує індивідуальні потреби таких осіб, визначені в індивідуальній програмі розвитку.

4. Для навчання, професійної підготовки або перепідготовки осіб 3 особливими освітніми потребами застосовуються види та форми здобуття освіти, що враховують їхні потреби та індивідуальні можливості.

5. Органи державної влади, органи місцевого самоврядування та заклади освіти створюють умови для здобуття освіти особами з особливими освітніми потребами шляхом забезпечення розумного пристосування та універсального дизайну.

6. Навчання та виховання осіб $з$ особливими освітніми потребами, зокрема тими, що спричинені порушенням розвитку та інвалідністю, у закладах дошкільної, позашкільної та середньої освіти здійснюються за рахунок коштів освітніх субвенцій, державного та місцевих бюджетів, інших джерел, не заборонених законодавством, у тому числі з урахуванням потреб дитини, визначених в індивідуальній програмі розвитку.

7. Зарахування осіб з особливими освітніми потребами до спеціальних закладів освіти, переведення з одного типу закладу до іншого та відрахування таких осіб здійснюються у порядку, встановленому центральним органом виконавчої влади у сфері освіти і науки.

8. Категорії осіб з особливими освітніми потребами визначаються актами Кабінету Міністрів України»

У статті 20 Закону України «Про освіту» 2017 р.: «Інклюзивне навчання» визначено, що:

1. Заклади освіти за потреби утворюють інклюзивні та/або спеціальні групи і класи для навчання осіб з особливими освітніми потребами. У разі звернення особи з особливими освітніми потребами або їі батьків така група або клас утворюється в обов'язковому порядку. 


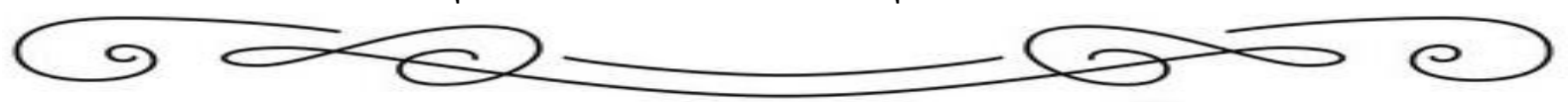

2. Заклади освіти зі спеціальними та інклюзивними групами і класами створюють умови для навчання осіб 3 особливими освітніми потребами відповідно до індивідуальної програми розвитку та 3 урахуванням їхніх індивідуальних потреб і можливостей.

3. Особи 3 порушеннями фізичного, психічного, інтелектуального розвитку i сенсорними порушеннями забезпечуються у закладах освіти допоміжними засобами для навчання.

4. Особам з особливими освітніми потребами надаються психологопедагогічні та корекційно-розвиткові послуги у порядку, визначеному центральним органом виконавчої влади у сфері освіти і науки.

Психолого-педагогічні послуги - це комплексна система заходів 3 організації освітнього процесу та розвитку особи 3 особливими освітніми потребами, що передбачені індивідуальною програмою розвитку та надаються педагогічними працівниками закладів освіти, реабілітаційних установ системи охорони здоров'я, соціального захисту, фахівцями інклюзивно-ресурсного центру.

Корекційно-розвиткові послуги (допомога) - це комплексна система заходів супроводження особи з особливими освітніми потребами у процесі навчання, що спрямовані на корекцію порушень шляхом розвитку особистості, її пізнавальної діяльності, емоційно-вольової сфери та мовлення.

5. Органи державної влади та органи місцевого самоврядування утворюють інклюзивно-ресурсні центри з метою забезпечення реалізації права на освіту та психолого-педагогічний супровід дітей 3 особливими освітніми потребами.

Психолого-педагогічний супровід - це комплексна система заходів 3 організації освітнього процесу та розвитку дитини, передбачена індивідуальною програмою розвитку.

6. Будівлі, споруди і приміщення закладів освіти повинні відповідати вимогам доступності згідно з державними будівельними нормами і стандартами.

7. Проєктування, будівництво та реконструкція будівель, споруд, приміщень закладів освіти здійснюються з урахуванням принципів універсального дизайну та/або розумного пристосування.

Так, у Законі України «Про внесення змін до деяких законів України про освіту щодо організації інклюзивного навчання» від 2014 року, зазначено, що «у всіх типах дошкільних навчальних закладів при реалізації права дітей на дошкільну освіту враховуються особливі освітні потреби у навчанні і вихованні кожної дитини, у тому числі дітей з особливими освітніми потребами відповідно до принципів інклюзивної освіти», а «вихователя загальноосвітньої спеціальної школи (школи-інтернату)» доповнити словами «та асистента вчителя інклюзивних класів загальноосвітніх навчальних закладів» [1].

У Постанові Кабінету Міністрів України «Про внесення змін до деяких постанов Кабінету Міністрів України» від 2016 року, слова «свідоцтв про закінчення спеціальної загальноосвітньої школи (для дітей, що мають вади у фізичному чи розумовому розвитку)» замінити словами «свідоцтв про базову загальну середню освіту за спеціальною програмою (для учнів з порушеннями

Вип. 3, 2019

ISSN 2618-0715 


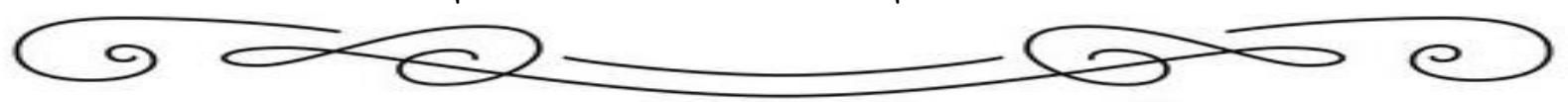

розумового розвитку) та довідок про закінчення повного курсу навчання за спеціальною програмою (для учнів з помірною розумовою відсталістю)» [4].

Всі ці зміни до законопроєктів та постанов уряду, у свою чергу сприяло підвищенню ролі інклюзивної освіти та виділення їі із широкого загалу.

Так, у Постанові Кабінету Міністрів України «Деякі питання створення ресурсних центрів підтримки інклюзивної освіти та інклюзивно-ресурсних центрів» № 617 від 22.08.2018 зазначено, що основними завданнями центру підтримки інклюзивної освіти є:

1) здійснення методичного та аналітичного забезпечення діяльності інклюзивно-ресурсних центрів;

2) методичне забезпечення навчання та підвищення кваліфікації педагогічних працівників інклюзивно-ресурсних центрів, закладів освіти щодо навчання дітей з особливими освітніми потребами;

3) здійснення аналітичної та прогностичної діяльності щодо організації навчання дітей з особливими освітніми потребами у відповідній області, мм. Києві та Севастополі;

4) проведення аналізу даних реєстру дітей, які пройшли комплексну психолого-педагогічну оцінку розвитку дитини (далі - комплексна оцінка) i перебувають на обліку в інклюзивно-ресурсних центрах у відповідній області, мм. Києві та Севастополі за згодою батьків (одного 3 батьків) або законних представників на обробку персональних даних неповнолітньої дитини;

5) підвищення рівня обізнаності громадськості про дітей 3 особливими освітніми потребами, у тому числі з інвалідністю, запобігання дискримінації, формування позитивного ставлення до таких дітей та їх батьків [5].

Відповідно до вищевказаної Постанови Кабінету Міністрів України від 22.08.2018 року, у якій зазначено, що Центр підтримки інклюзивної освіти відповідно до покладених на нього завдань:

1) здійснює підвищення професійної компетентності педагогічних працівників інклюзивно-ресурсних центрів, закладів освіти щодо навчання дітей 3 особливими освітніми потребами шляхом організації та проведення, зокрема, тренінгів, семінарів, вебінарів;

2) надає консультативно-методичну допомогу з питань навчання дітей 3 особливими освітніми потребами керівникам та педагогічним працівникам закладів освіти, інклюзивно-ресурсних центрів, установ (закладів) соціального захисту населення, закладів охорони здоров'я, батькам (іншим законним представникам) дитини, посадовим особам обласних (Київської та Севастопольської міських) держадміністрацій, представникам органів місцевого самоврядування та громадським об'єднанням;

3) проводить аналіз даних щодо фахівців, які надають психологопедагогічні, корекційно-розвиткові послуги дітям 3 особливими освітніми потребами у відповідній області, мм. Києві та Севастополі (їх професійний рівень, місце роботи);

4) здійснює узагальнення інформації про заклади освіти відповідної області, м.Києва та Севастополя, які надають психолого-педагогічні та 


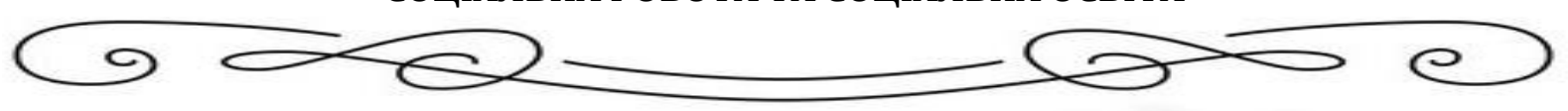

корекційно-розвиткові послуги дітям з особливими освітніми потребами;

5) проводить аналіз даних щодо охоплення навчанням дітей з особливими освітніми потребами у відповідній області, мм. Києві та Севастополі, вивчає та узагальнює досвід роботи закладів освіти;

6) надає в межах компетенції пропозиції щодо удосконалення законодавства з питань навчання дітей з особливими освітніми потребами відповідному структурному підрозділу 3 питань діяльності інклюзивно-ресурсних центрів органів управління освітою обласних, Київської та Севастопольської міських держадміністрацій та МOH;

7) співпрацює з Інститутом спеціальної педагогіки Національної академії педагогічних наук та іншими структурними підрозділами закладу післядипломної педагогічної освіти щодо застосування сучасних методик проведення комплексної оцінки, надання психолого-педагогічних та корекційно-розвиткових послуг, адаптації освітніх програм до потреб дітей з особливими освітніми потребами, розробки індивідуальної програми розвитку та з інших питань в межах своєї компетенції;

8) проводить інформаційно-просвітницьку роботу з підвищення рівня обізнаності громадськості про дітей з особливими освітніми потребами, у тому числі з інвалідністю, у взаємодії з громадськими об'єднаннями, батьками (іншими законними представниками) дітей, закладами освіти шляхом організації та проведення лекцій, тренінгів, семінарів, вебінарів, поширення інформаційних матеріалів у засобах масової інформації тощо [5].

У посібнику за авторством М. Порошенко зазначено, що «у розвитку дитини з ООП можна визначити декілька етапів її соціалізації. Перший етап передбачає входження дитини в соціум. На цьому етапі соціалізація дитини з ООП не може бути досягнута без залучення до цього процесу її батьків. Сім'я як соціальний інститут покликана соціалізувати дитину. Другий етап - це, власне перебування дитини у закладі освіти. Інклюзивна освіта $\epsilon$ важливим аспектом у цьому питанні. Головними агентами шкільної соціалізації $\epsilon$ вчителі, які, виконуючи покладені на цей інститут завдання, мають створити проміжну модель стосунків дітей із соціальним світом. Третій етап соціалізації дитини 3 оОП вважається їі самоствердження, реалізація їі соціального потенціалу в соціумі. Соціальноекономічними умовами успішної соціалізації в соціумі $є$ : раннє виявлення дітей $з$ ОоП; економічна підтримка сімей, які виховують дитину 3 оОП; соціальнопедагогічна робота з неблагополучними сім'ями; соціально-педагогічний супровід багатодітних сімей, молодих сімей та ін.» [3, с. 95-101].

У 2019 році планується перша та єдина в Україні спеціалізована виставка Інклюзивна Україна 2019, що присвячена інклюзивному обладнанню, технологіям та устаткуванню для людей 3 інвалідністю. Головними розділами експозиції присвячені таким питанням, як:

- мобільні системи та пристрої для руху;

- засоби для адаптації у повсякденному житті;

- обладнання для реабілітації та догляду.

А серед питань для обговорення, виокремлюють:

Вип. 3, 2019

ISSN 2618-0715 


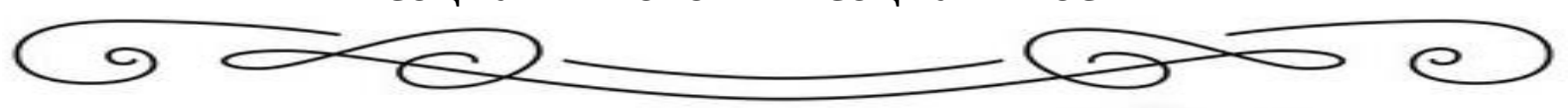

1) Бар'єрність, як найголовніша проблема для маломобільних груп населення;

2) Запуск міських програм по забезпеченню обладнанням та спец. засобами людей з інвалідністю: головні пріоритети;

3) Забезпечення прав осіб з інвалідністю: що і як можна змінити в чинному законодавстві?

4) Фінансування допомоги людям 3 інвалідністю: як підтримати i розширити практику благодійності?

5) Взаємодія міських органів влади з громадськими організаціями у питаннях підтримки людей з інвалідністю

6) Організація реабілітації людей з інвалідністю: ключові проблеми;

7) Кроки щодо популяризації концепції інклюзивності у суспільстві [2].

Інтеграція України до Європейського освітнього простору, змушує щороку нашу державу ратифікувати міжнародні договори та забезпечувати для дітей 3 інвалідністю відкриту та доступну освіту на всіх її ланках.

Отже, в Україні діє грунтовна нормативно правова база щодо забезпечення якісної та доступної інклюзивної освіти для дітей з інвалідністю. У закладах 3 інклюзивним навчанням надаються психолого-педагогічні та корекційнорозвиткові послуги у порядку, визначеному центральним органом виконавчої влади у сфері освіти і науки. А соціальна адаптація дітей з інвалідністю буде успішною в результаті виконання дитиною ряду ролей, зокрема, Я - успішний учень, Я - успішний працівник, Я - свідомий громадянин, тому що соціалізація дитини - це процес і результат засвоєння дитиною певних знань і вмінь, навичок, цінностей, що дає змогу стати їй дієздатною і повноцінним громадянином.

Окреслене дослідження не вичерпує усіх аспектів проблеми, а подальшим напрямком дослідження може стати характеристика обладнання, технологій та устаткування для дітей з інвалідністю в закладах з інклюзивним навчанням.

\section{СПИСОК ВИКОРИСТАНИХ ДЖЕРЕЛ}

1. Про внесення змін до деяких законів України про освіту щодо організації інклюзивного навчання: Закон України № 30 від 05.06.2014. URL: https://zakon.rada.gov.ua/laws/show/1324-18.

2. Національна Асамблея людей з інвалідністю в Україні. Програма: «нклюзивна Україна 2019». URL: https://naiu.org.ua/zaproshuyemo-do-uchasti-inklyuzyvna-ukrayina-2019/.

3. Порошенко М. А. Інклюзивна освіта: навч. посіб. Київ: ТОВ «Агентство «Україна», 2019. 300 с.

4. Про внесення змін до деяких постанов Кабінету Міністрів України: Постанова Кабінету Міністрів України № 671 від 27.09.2017. URL: https://zakon3.rada.gov.ua/laws/show/671-2016$\%$ D0\%BF.

5. Деякі питання створення ресурсних центрів підтримки інклюзивної освіти та інклюзивноресурсних центрів: Постанова Кабінету Міністрів України № 617 від 22.08.2018. URL: https://zakon.rada.gov.ua/laws/show/617-2018-\%D0\%BF.

6. Хамініч С. Ю., Переверзева О.В. Інклюзивна освіта в контекстів інноваційного розвитку України. URL: http://confcontact.com/2013_03_15/35_Haminich.htm.

\section{REFERENCES}

1. Pro vnesennia zmin do deiakykh zakoniv Ukrainy pro osvitu shchodo orhanizatsii inkliuzyvnoho navchannia: Zakon Ukrainy № 30 vid 05.06.2014. URL: https://zakon.rada.gov.ua/laws/show/1324-18 [in Ukrainian]. 


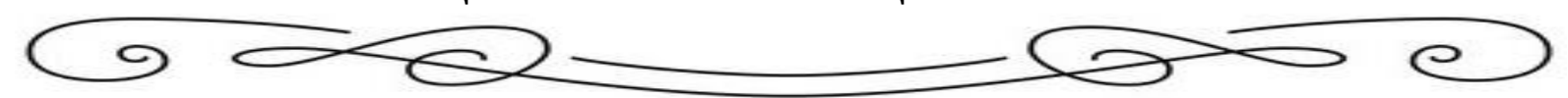

2. Natsionalna Asambleia liudei z invalidnistiu v Ukraini. Prohrama: «Inkliuzyvna Ukraina 2019». URL: https://naiu.org.ua/zaproshuyemo-do-uchasti-inklyuzyvna-ukrayina-2019/ [in Ukrainian].

3. Poroshenko M. A. (2019). Inkliuzyvna osvita: navchalnyi posibnyk. Kyiv: TOV «Ahentstvo «Ukraina» [in Ukrainian].

4. Pro vnesennia zmin do deiakykh postanov Kabinetu Ministriv Ukrainy: Postanova Kabinetu Ministriv Ukrainy № 671 vid 27.09.2017. URL: https://zakon3.rada.gov.ua/laws/show/671-2016-\%D0\%BF [in Ukrainian].

5. Deiaki pytannia stvorennia resursnykh tsentriv pidtrymky inkliuzyvnoi osvity ta inkliuzyvnoresursnykh tsentriv: Postanova Kabinetu Ministriv Ukrainy №617 vid 22.08.2018. URL: https://zakon.rada.gov.ua/laws/show/617-2018-\%D0\%BF [in Ukrainian].

6. Khaminich S. Iu., Pereverzeva O. V. (2013). Inkliuzyvna osvita v kontekstiv innovatsiinoho rozvytku Ukrainy. URL: http://confcontact.com/2013_03_15/35_Haminich.htm [in Ukrainian]. 